\title{
Removal of quaternary ammonium compounds in ion exchange process
}

\author{
Aleksandra Klimonda ${ }^{1, *}$, and Izabela Kowalska ${ }^{1}$ \\ ${ }^{1}$ Wroclaw University of Science and Technology, Faculty of Environmental Engineering, \\ Wybrzeże S. Wyspiańskiego 27, 50-370 Wrocław, Poland
}

\begin{abstract}
The study attempted to evaluate the effectiveness of ion exchange process in cationic surfactant (benzalkonium chloride, BAC) removal from model solutions. Four commercial cation-exchange resins were chosen for the batch tests in four doses $\left(2.5-20 \mathrm{~mL} \mathrm{~L}^{-1}\right)$. The experiments included evaluation of the following parameters on ion exchange efficiency: resin characteristics and dose, presence of inorganic salt and $\mathrm{pH}$ of treated solution. The ion exchange process was found to be very effective in cationic surfactant removal - two of tested resins allowed to remove up to $80 \%$ of contaminant after contact time of 40 minutes, the last two - after 60 minutes of mixing in all range of doses. The presence of electrolyte neither $\mathrm{pH}$ change has no essential effect on surfactant removal efficiency. The analysis of the ion exchange isotherms showed that the strongly-acidic macroporous resin $\mathrm{C} 150 \mathrm{H}$ was characterized by the highest BAC ion exchange capacity $\left(153.8 \mathrm{mg} \mathrm{mL}^{-1}\right)$, while the weakly-acidic gel resin $\mathrm{C} 104$ showed the best affinity of the exchanged ions to the resin matrix.
\end{abstract}

\section{Introduction}

In the $21^{\text {st }}$ century the fresh water deficiency become a significant problem. Progressive urban and industrial development leads to large water demand. In order to conserve the water resources, most countries implement recycling and reuse of wastewater [1]. However, some anthropological contaminants like surfactants may be difficult to remove from wastewater in conventional methods.

Surfactants are a group of organic compounds consisting of hydrophilic heads and hydrophobic tails. They have been widely used as detergents, wetting agents, emulsifiers, foaming agents as well as dispersants [2]. Depending on hydrophilic part dissociating ion, surfactants are classified into four groups: anionic, cationic, non-ionic and zwitterionic. Quaternary ammonium salts such as benzalkonium chloride (BAC) are the major and most abundant contributing cationic surfactant constituents. BAC is commonly used as biocide, preservative, pesticide, antifungal agent due to its destructive action versus cells [3]. Due to the diversity of surfactants and their physico-chemical properties it is difficult to develop a single and an effective treatment method of surfactant-contaminated wastewater. Literature data survey evidence that such processes as biodegradation, coagulation, foaming,

\footnotetext{
*Corresponding author: aleksandra.klimonda@pwr.edu.pl
} 
photocatalytic oxidation and membrane technology [4-9] may found application in surfactants removal. Moreover, many research involving surfactants removal is focused on adsorption methods with the use of such adsorbents as activated carbon, carbon nanotubes, clays, sand, minerals (zeolite, akageneite) or ashes [10-16]. Taking into account the ionic character of surfactants, it was found that the ion exchange process may be a suitable method for surfactants removal [17], moreover ion exchange resins may be more effective in surfactants removal than conventional adsorbents. Schuricht et al. [17] compared removal efficiency of perfluorinated surfactants from wastewater by adsorption on activated carbon and ion exchange with the use of anion exchange resins. The ion exchange and hydrophobic interaction were found to be involved in the sorption processes on resins, while for activated carbon, surfactant removal is only due to physisorptively bound to activated carbons. Schouten et al. [18] reported anion exchanger IRA-900 capacity versus anionic surfactant linear alkyl benzene sulfonate (LAS) equal to $3.7 \mathrm{mmol} \mathrm{LAS} / \mathrm{g}$ dry resin which is relatively high and close to the specified ion exchange capacity of $4.2 \mathrm{meq} / \mathrm{g}$ dry resin.

\section{Experimental}

Quaternary ammonium compound, benzalkonium chloride (BAC) was subject of the tests (Table 1). Model solutions containing 50, 100 and $250 \mathrm{mg} \mathrm{BAC} \mathrm{L}^{-1}$ were prepared from distilled water and benzalkonium chloride (BAC). The concentration of surfactant was determined using spectroscopic measurements (UV Mini 1240 spectrophotometer, Shimadzu). In order to verify the effect of electrolyte on the process efficiency, sodium chloride $(\mathrm{NaCl}$, Poch, Poland) was added to prepared solutions. $\mathrm{pH}$ correction was achieved by adding $0.1 \mathrm{M} \mathrm{HCl}$ and $0.1 \mathrm{M} \mathrm{NaOH}$ solutions to prepared feeds. $\mathrm{pH}$ value of $\mathrm{BAC}$ solutions without any correction amounted to 6.8-7.1. HQ11D pH meter, Hach was employed for $\mathrm{pH}$ analysis.

Table 1. Characteristics of benzalkonium chloride.

\begin{tabular}{|c|c|}
\hline Name & BAC (benzalkonium chloride) \\
\hline Type & cationic \\
\hline Chemical structure & \\
& \\
\hline Molecular weight, $\mathrm{Da}$ & $283.80-423.97$ \\
\hline Carbon atoms in chain & $8-18$ \\
\hline CMC, $\mathrm{g} \mathrm{L}^{-1}$ & $5.9 \pm 0.5$ at $22^{\circ} \mathrm{C}$ \\
\hline Monomer length, $\mathrm{nm}$ & $80 \%$ \\
\hline Purity & \\
\hline
\end{tabular}

Four cation exchange resins which characteristics is presented in Table 2 were used in the experiments. Brand new resins $\mathrm{C} 150 \mathrm{H}$, Dowex 88 and Marathon 1200 were regenerated with the use of $12 \% \mathrm{NaCl}$ solution and soaked in distilled water until regeneration agent vanished. A weakly-acidic $\mathrm{C} 104$ plus resin were applied in hydrogen form. The ion exchange process was carried out in $2 \mathrm{~L}$ reactors containing $1 \mathrm{~L}$ of the solution and charged with resin doses of 2.5, 5, 10 and $20 \mathrm{~mL}$. The reactors were placed on Velp Scientifica FC6S flocculator and stirred at the rotational speed of $150 \mathrm{rpm}$, which ensured the uniform distribution of the resin within the entire volume of the solution. Samples were collected for BAC concentration measurement after pre-defined mixing periods (5-120 $\mathrm{min})$. 
Table 2. Characteristics of cation exchange resins

\begin{tabular}{|c|c|c|c|c|c|}
\hline Resin & Type & Structure & $\begin{array}{c}\text { Functional } \\
\text { group }\end{array}$ & $\begin{array}{c}\text { Grain size, } \\
\boldsymbol{\mu m}\end{array}$ & $\begin{array}{c}\text { Exchange } \\
\text { capacity }^{*}, \\
\text { eq L L }^{-1}\end{array}$ \\
\hline $\mathrm{C} 150 \mathrm{H}$ & $\begin{array}{c}\text { strong } \\
\text { acidic }\end{array}$ & $\begin{array}{c}\text { polystyrene crosslinked with } \\
\text { divinylbenzene, macroporous }\end{array}$ & sulfonate & $600-850$ & 1.7 \\
\hline Dowex 88 & $\begin{array}{l}\text { strong } \\
\text { acidic }\end{array}$ & styrene-DVB, macroporous & sulfonate & $300-1200$ & 1.8 \\
\hline $\begin{array}{c}\text { Marathon } \\
1200 \mathrm{Na}\end{array}$ & $\begin{array}{c}\text { strong } \\
\text { acidic }\end{array}$ & styrene-divinylbenzene, gel & sulfonate & $535-635$ & $\geq 2.0$ \\
\hline C104 plus & weak acidic & crosslinked polyacrylic acid, gel & carboxylic & $300-1200$ & 4.2 \\
\hline
\end{tabular}

* producer data

Ion exchange isotherms can be described by numerous mathematical models. In this paper, the classical approach of the linear-form of Langmuir model was analyzed:

$$
\frac{C_{e}}{q_{e}}=\frac{1}{q_{\max } K_{L}}+\frac{C_{e}}{q_{\max }}
$$

where: $q_{e}\left(\mathrm{mg} \mathrm{mL}^{-1}\right)$ - equilibrium amount of BAC exchanged on a resin volume of $1 \mathrm{~mL}$ calculated from the following equation:

$$
q_{e}=\left(C_{i}-C_{e}\right) \frac{V}{V_{J}}
$$

where: $C_{i}\left(\mathrm{mg} \mathrm{L}^{-1}\right)$ - initial BAC concentration, $C_{e}\left(\mathrm{mg} \mathrm{L}^{-1}\right)$ - equilibrium BAC concentration, $V(\mathrm{~L})$ - solution volume, $V_{J}(\mathrm{~mL})$ - resin volume, $q_{\max }\left(\mathrm{mg} \mathrm{mL}^{-1}\right)-$ maximum uptake of BAC exchanged on a resin volume of $1 \mathrm{~mL}, K_{L}\left(\mathrm{~L} \mathrm{mg}^{-1}\right)$ - Langmuir constant.

The efficiency of BAC removal was calculated from following formula:

$$
R=\frac{\left(C_{i}-C_{e}\right)}{C_{i}} \cdot 100, \%
$$

\section{Results and discussion}

Figures 1 and 2 present kinetic profiles obtained in the 120 min experiments. Similar course of curves was noted for all resins - increasing mixing time and resin dose resulted in BAC removal enhancement. It should be noted that in the first stage of the processes (up to $20 \mathrm{~min}$ ), the intensity of the ion exchange was the most dynamic. With the increase of mixing time, the kinetics of the ion exchange slowed down and the equilibrium state was achieved. Strongly-acidic resins $\mathrm{C} 150 \mathrm{H}$ and Marathon $1200 \mathrm{Na}$ established equilibrium after mixing time of 40 minutes (resin dose of 5, 10 and $20 \mathrm{~mL}$, initial BAC concentration of $50 \mathrm{mg} \mathrm{L}^{-1}$ ). Weakly-acidic resin $\mathrm{C} 104$ plus required longer contact time. It was also noted that increasing resin dose brought an improvement in BAC removal, ex. the increase of Marathon $1200 \mathrm{Na}$ 
dose in the range from 2.5 to $20 \mathrm{~mL}$ improved the removal efficiency from 50 to $100 \%$ for 20 min of mixing.

For all tested adsorbents in the dose of $2.5 \mathrm{~mL}$, it can be observed that equilibrium established after more than 60 minutes of mixing $(\mathrm{C} 150 \mathrm{H}$, Marathon $1200 \mathrm{Na})$ or even did not steadied during 120 minutes experiment (Dowex 88, C104 plus). The same phenomenon occurred when initial surfactant concentration increased. It may be deduced that with the decreasing of resin dose and increasing of the number of ions for exchange (BAC concentration), the process driving force rises. When the number of macroions per volume of resin increases, the potential difference between resin phase and solution phase grows. As a result, the larger number of BAC ions was attracted to the surface of the resin. Moreover, with the smaller volume of resin (per unit of surfactant volume), the competition between $\mathrm{BAC}$ molecules for active places occupation rise, thus establishing equilibrium state takes a longer time.
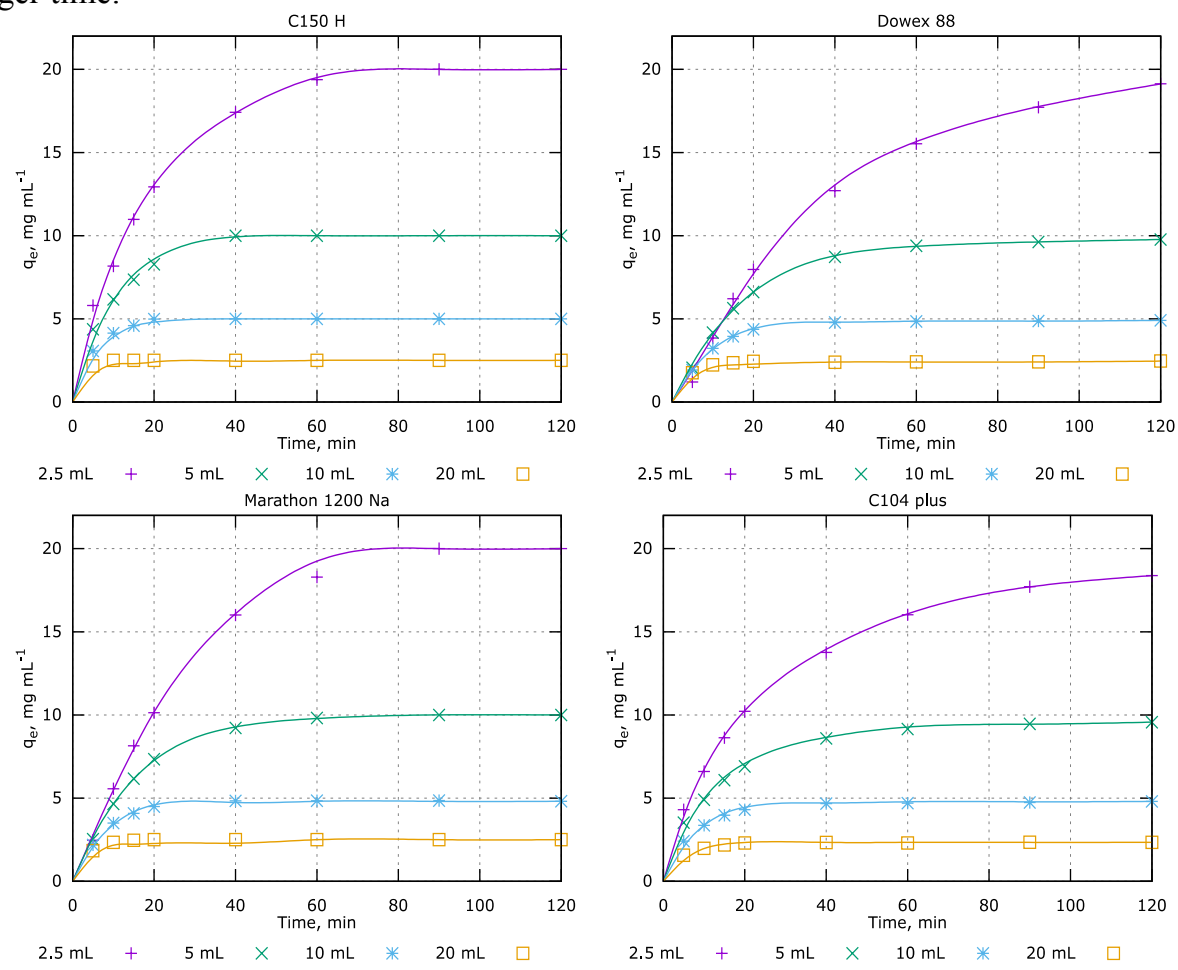

Fig. 1. The effect of contact time and ion-exchange resin dose on the efficiency of BAC removal from solution of initial concentration $50 \mathrm{mg} \mathrm{L}^{-1}$.

In order to verify the effect of $\mathrm{pH}$ on $\mathrm{BAC}$ removal in the ion exchange process, two resins (macroporous strongly-acidic and gel weakly-acidic) were applied. The initial BAC concertation amounted to $50 \mathrm{mg} \mathrm{L}^{-1}$. The results obtained are plotted in Figure 3. It can be observed that for strongly-acidic $\mathrm{C} 150 \mathrm{H}$ resin, the change in $\mathrm{pH}$ value did not bring any significant effect on surfactant removal efficiency. Only at the lowest $\mathrm{pH}$ value, a slight drop in removal was seen. Analysis of weakly-acidic C104 plus resin curves shows a big drop in process efficiency at $\mathrm{pH}=3$ comparing to data presented in Figure 2 (after 60 minutes of mixing, $100 \%$ of $\mathrm{BAC}$ was removed). At $\mathrm{pH}=3$, maximum removal did not exceed $50 \%$ after 120 minutes of mixing. Weak-acidic resins with carboxylic functional groups have $\mathrm{pK}_{\mathrm{a}}$ values below 6 [19], as a consequence, the degree of dissociation of these resins is 
strongly influenced by the solution $\mathrm{pH}$ - functional groups will not readily give up a proton unless the $\mathrm{pH}$ is greater than 6 . At a $\mathrm{pH}$ lower than 6 , weak-acidic resins have greater affinity to hydrogen and will not exchange it for another cations [20]. As a result, for low $\mathrm{pH}$ values, process is limited and less BAC macroions may be bounded to the active sites.
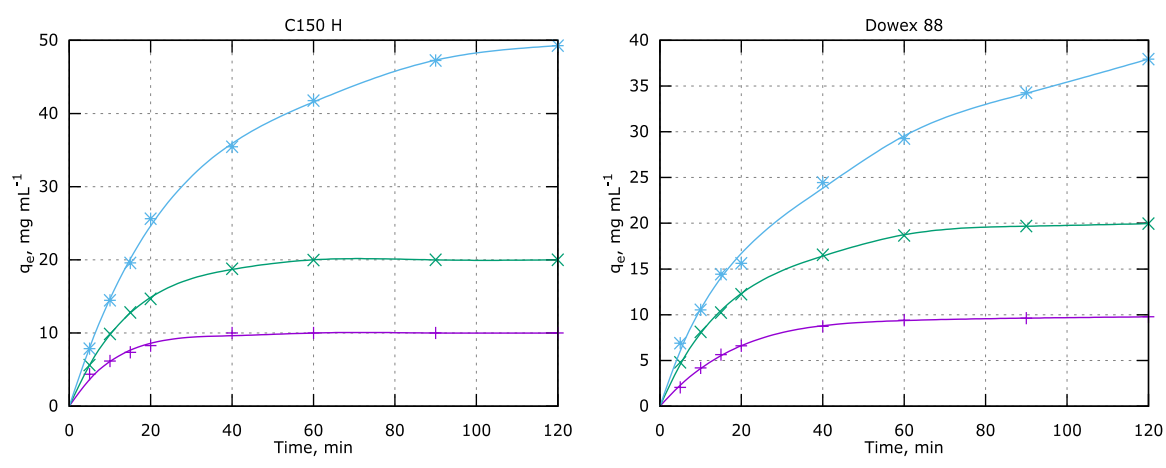

$50 \mathrm{mg} \mathrm{L}^{-1}+100 \mathrm{mg} \mathrm{L}^{-1} \times 250 \mathrm{mg} \mathrm{L}^{-1}$

$50 \mathrm{mg} \mathrm{L}^{-1}+100 \mathrm{mg} \mathrm{L}^{-1} \times 250 \mathrm{mg} \mathrm{L}^{-1}$
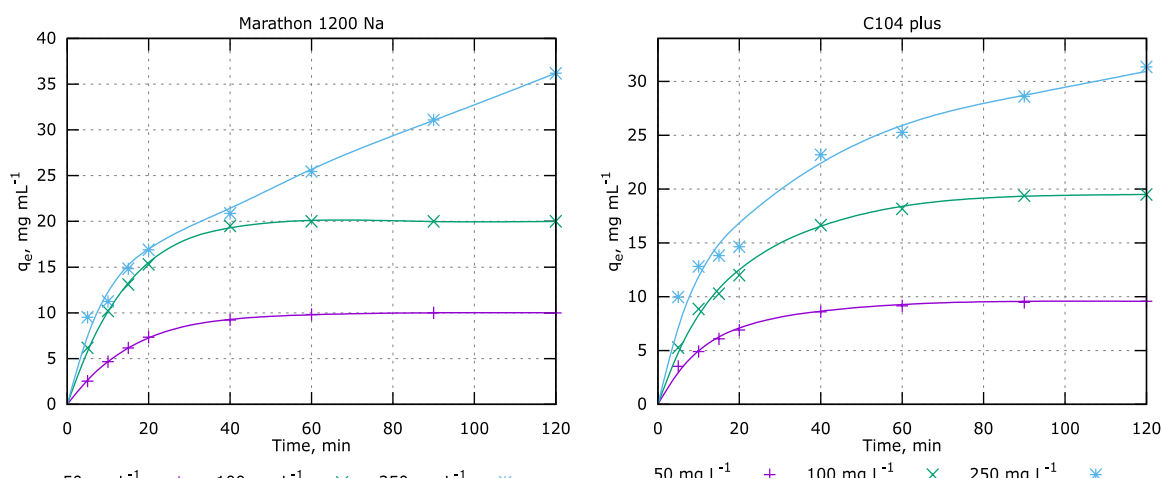

$50 \mathrm{mg} \mathrm{L}^{-1}+100 \mathrm{mg} \mathrm{L}^{-1} \times 250 \mathrm{mg} \mathrm{L}^{-1}$

$50 \mathrm{mg} \mathrm{L}^{-1}+100 \mathrm{mg} \mathrm{L}^{-1} \times 250 \mathrm{mg} \mathrm{L}^{-1}$

Fig. 2. The effect of contact time and BAC concentration on the efficiency of BAC removal (resin dose $5 \mathrm{~mL}$ ).

Figure 4 presents the effect of inorganic salt $(\mathrm{NaCl})$ on $\mathrm{BAC}$ removal for all resins analyzed in this study. It was noted that for Dowex 88 resin, the presence of electrolyte brought an essential deterioration in removal efficiency, and for the resin dose of $2.5 \mathrm{~mL}$ this phenomenon was more pronounced than for dose of $5 \mathrm{~mL}$. For example, after mixing time of $20 \mathrm{~min}, \mathrm{BAC}$ removal amounted to $39.8 \%$ and to $70.5 \%$ for resin dose of 5 and $10 \mathrm{~mL}$, respectively (salt concentration of $0.5 \mathrm{~g} \mathrm{~L}^{-1}$ ). Increasing salt content from 0.5 to $1 \mathrm{~g} \mathrm{~L}^{-1} \mathrm{did}$ not affect BAC removal - retention coefficient changed from 39.8 to $37.8 \%$ and from 70.5 and $73.9 \%$ for resin dose of 5 and $10 \mathrm{~mL}$, respectively. 

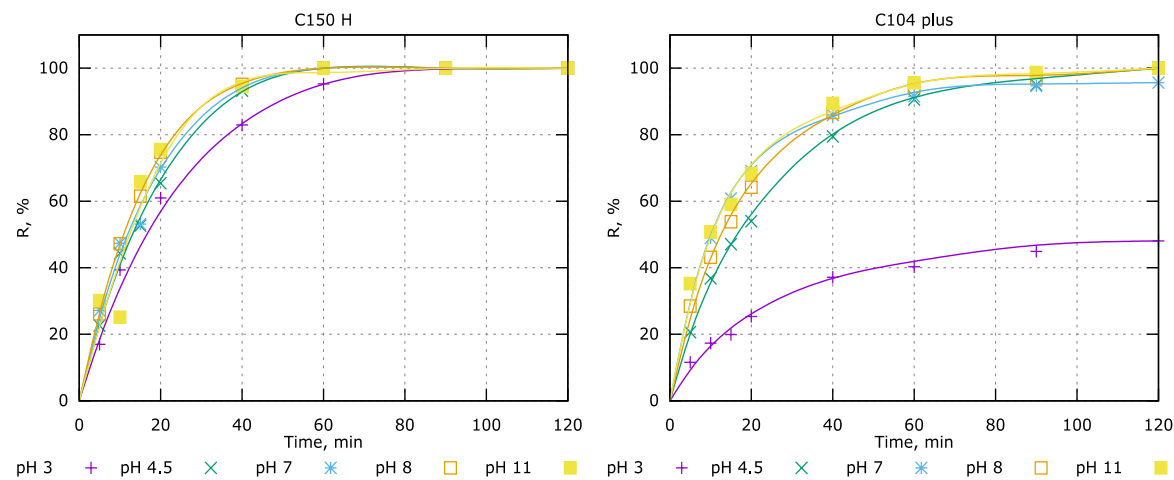

Fig. 3. The effect of contact time and $\mathrm{pH}$ on the efficiency of BAC removal efficiency from solution of initial concentration $50 \mathrm{mg} \mathrm{L}^{-1}$, resin dose $5 \mathrm{~mL}$.
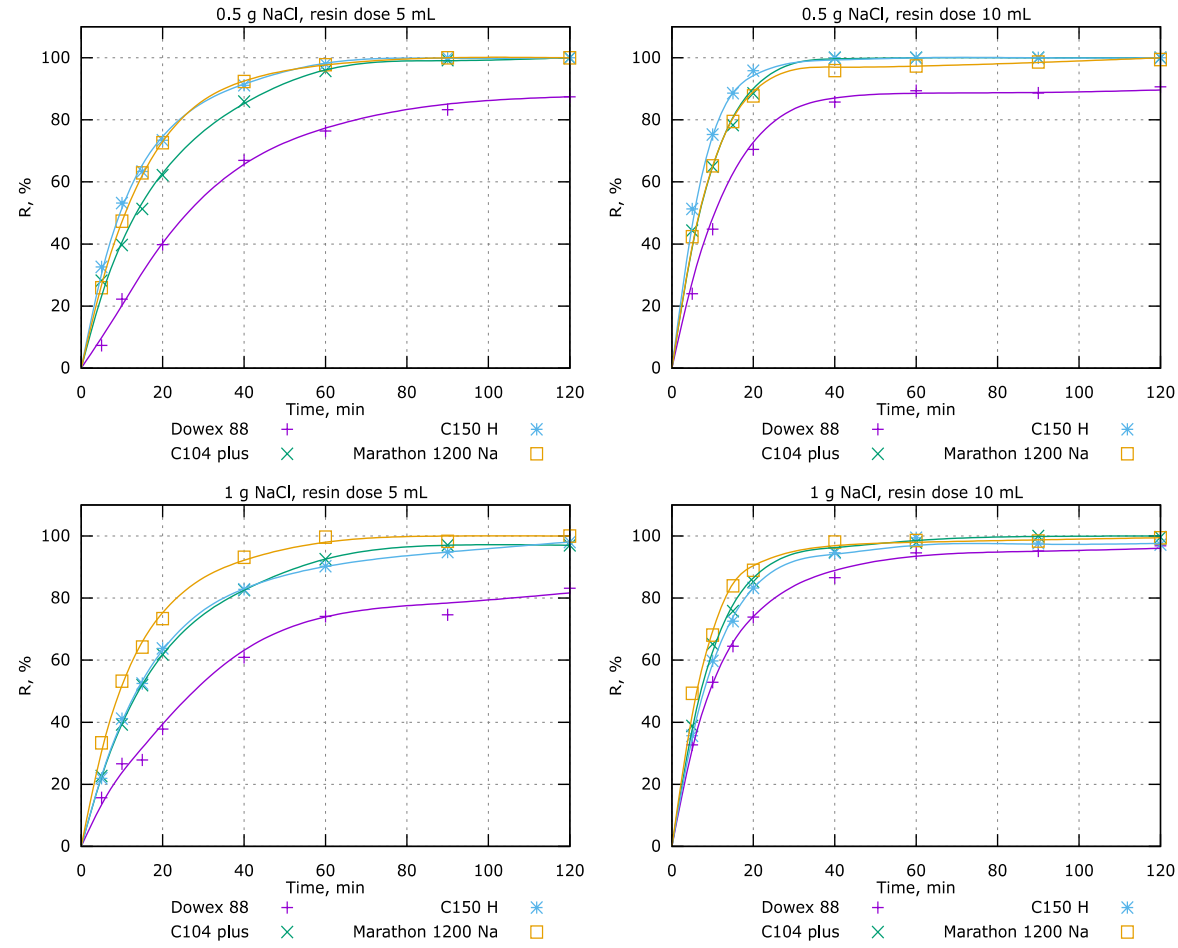

Fig. 4. The effect of contact time and addition of electrolyte on the efficiency of BAC removal from solution of initial concentration $50 \mathrm{mg} \mathrm{L}^{-1}$.

Based on the linear-form of Langmuir model (equations 1 and 2) and the tangent of the slope angle of the curve $\mathrm{f}\left(C_{e}\right)=C_{e} / q_{e}$ (Figure 5), the parameters $\mathrm{q}_{\max }$ and $K_{L}$ were calculated for all tested resins and compared in Table 3. Maximum exchange capacity values ( $q_{\max }$, maximum uptake of BAC exchanged on a resin volume unit) listed from the highest to the lowest amounted to $158.3,116.3,103.1$ and $77.5 \mathrm{mg} \mathrm{mL}^{-1}$ for $\mathrm{C} 150 \mathrm{H}$, Marathon $1200 \mathrm{Na}$, Dowex 88 and C104 plus resins, respectively. In accordance to the previous part of the study, the strongly-acidic macroporous resin $\mathrm{C} 150 \mathrm{H}$ proved to be the most suitable for BAC removal against all tested resins. Gel resins, C104 plus and Marathon $1200 \mathrm{Na}$ achieved worse ion exchange capacity. This is due to higher degree of polymer crosslinking 
(comparing to macroporous resins) - surfactant monomers access to the active sites of gel resins is limited by the compact structure of the matrix. Due to the relatively large grain size $(300-1200 \mu \mathrm{m})$ of macroporous resin Dowex 88, BAC macroions penetration to the resin's active sites was restricted. As a result, this resin showed a worse capacity than the gel resin Marathon $1200 \mathrm{Na}$.

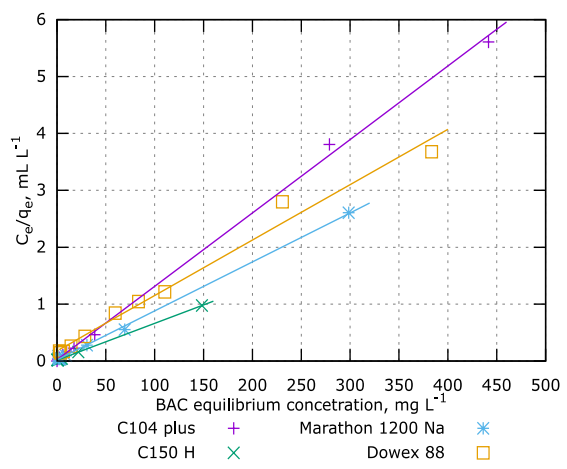

Fig. 5. The linear form of benzalkonium chloride ion exchange isotherms.

$K_{L}$ (Langmuir constant) parameter is being used for evaluation the affinity of ions exchanged to the resin structural polymer. Taking into account $\mathrm{K}_{\mathrm{L}}$ values, Dowex 88 resin showed the lowest affinity, which may explain BAC removal deterioration in the presence of inorganic salt (Figure 4). As a result of low BAC affinity to Dowex 88 resin, other ions (e.g. $\mathrm{Na}^{+}$) are being exchanged preferentially limiting at the same time BAC removal. $\mathrm{C} 104$ plus resin achieved the highest value of $\mathrm{K}_{L}$ parameter, however this weakly-acidic gel resin cannot remove such number of surfactant macroions as macroporous strongly-acidic resin due to the lower pore size and the worse selectivity.

Table 3. Langmuir isotherms parameters for benzalkonium chloride ion exchange.

\begin{tabular}{|c|c|c|c|c|}
\hline Parameter & C150 H & Dowex 88 & $\begin{array}{c}\text { Marathon 1200 } \\
\text { Na }\end{array}$ & C104 plus \\
\hline$q_{\max }, \mathrm{mg} \mathrm{mL}^{-1}$ & 153.8 & 103.1 & 116.3 & 77.5 \\
\hline$K_{L}, \mathrm{~L} \mathrm{mg}^{-1}$ & 0.478 & 0.055 & 0.424 & 0.603 \\
\hline
\end{tabular}

\section{Summary}

- The research conducted proved the ion exchange process is an effective method for benzalkonium chloride removal from water. The process efficiency enhanced with extending mixing time and increasing resin dose.

- The change in $\mathrm{pH}$ value of the treated solution has no significant effect on surfactant removal with the use of strongly-acidic resin. Weak-acidic resin which degree of the functional groups' dissociation is dependent on solution $\mathrm{pH}$, showed decrease in BAC removal at low $\mathrm{pH}$ value.

- The resin matrix (gel or macroporous) and the grain size affect the macroions access to the active sites, thus - on the ion exchange efficiency.

\section{References}

1. T. Ramcharan, A. Bissessur, J. Surfact. Deterg. 19, 209-218 (2016) 
2. Q. Gao, W. Chen, Y, Chen, D. Werner, G. Cornelissen, B. Xing, S. Tao, X. Wang, Water Res. 106, 531-538 (2016)

3. V. Di Nica, J. Gallet, S. Villa, V. Mezzanotte, Ecotox. Environ. Safe. 142, 567-577 (2017)

4. J. Rivera-Utrilla, M. I. Bautista-Toledo, M. Sánchez-Polo, J. D. Méndez-Diáz, Eng. Life Sci. 12, 1, 113-116 (2012)

5. M. A. Aboulhassan, S. Souabi, A. Yaacoubi, M. Baudu, Int. J. Environ. Sci. Tech. 3, 4, 327-332 (2006)

6. S. Boonyasuwat, S. Chavadej, P. Malakul, J. F. Scamehorn, Chem. Eng. J. 93, 3, 241-252 (2003)

7. B. Czech, Annales UMCS. Sectio AA 66, 1, 2, 81-93 (2011)

8. C. A. Basar, A. Karagunduz, A. Cakici, B. Keskinler, Water Research 38, 2117-2124 (2004)

9. L. Suárez, M.A. Díez, R. García, F.A. Riera, J. Ind. Eng. Chem 18, 6, 1859-1873 (2012)

10. P. Das Purakayastha, A. Pal, M. Bandyopadhyay, Indian J. Chem. Techn. 12, 281-284 (2005)

11. O. V. Makarchuk, T. A. Dontsova, Journal of Water Security 2, 1-9 (2016)

12. A. A. Siyal, M. R. Shamsuddin, N. E. Rabat, M. Zulfiqar, M. Ayoub, K. A. Azizli, IOP Conf. Ser.: Mater. Sci. Eng. 458, 1-6 (2018)

13. J. Mao, D. Wang, X. Yang, Z. Zhang, B. Yang, C. Zhang, J. Taiwan Inst. Chem. E. 95, 424-431 (2019)

14. Z. Li, From Zeolites to Porous MOF Materials ( $40^{\text {th }}$ Anniversary of International Zeolite Conference 2098-2103, 2007)

15. N. Yekeen, M. A. Manan, A. K. Idris, A. M. Samin, J. Petrol. Sci. Eng. 149, 612-622 (2017)

16. M. N. Khan, U. Zareen, J. Hazard Mater. B133, 269-275 (2006)

17. F. Schuricht, E. S. Borovinskaya, W. Reschetilowski, J. Environ. Sci. 54, 160-170 (2017)

18. N. Schouten, L. G. J. van der Ham, G-J. W. Euverink, A. B. de Haan, Water Research 41, 4233-4241 (2007)

19. I. Singh, A. K. Rehni, R. Kalra, G. Joshi, M. Kumar, H. Y. Aboul-Enein, FABAD J. Pharm. Sci. 32, 91-100 (2007)

20. A. K. SenGupta, Ion Exchange in Environmental Processes: Fundamentals, Applications and Sustainable Technology (John Wiley \& Sons, Hoboken, 2017) 